\title{
Effect of Feeding Neem and Papaya Leaf Meal as Feed Additive on Carcass Characteristics and Economics of Broilers
}

\author{
Shiwani Singh", Ankur Khare, R. P. S. Baghel, Sunil Nayak, \\ Ravi Prakash Pal, Amit Chaurasiya and B. V. Reddy
}
Department of Animal Nutrition, College of Veterinary Science and Animal Husbandry, Jabalpur (Madhya Pradesh), India

*Corresponding author

\section{A B S T R A C T}

\section{Keywords}

Broilers, Neem leaf meal, Papaya leaf meal, Carcass characteristics and Economics

\section{Article Info}

Accepted:

22 January 2021

Available Online:

10 February 2021
The study was conducted to investigate the effect of supplementing neem and papaya leaf meal, individually and in combination on carcass characteristics and economics of broiler production. 220, day-old Cobb commercial broiler chicks were randomly divided into 11 treatments with 4 replicate having 5 chicks in each. In treatment groups along with basal diet, neem and papaya leaf meal were incorporated in the diet at two different levels, individually $(0.5$ and $1.0 \%$ of diet $)$ and in three different combinations $(1: 1,1: 2$ and 2:1 part of NLM and PLM @ 1.0 and 2.0\% of diet). Experiment was conducted for 6 weeks. At the end of trial (42 days), 02 birds from each replicate were sacrificed for performing carcass traits. Economics of broiler production was calculated as feed cost $/ \mathrm{kg}$ body weight gain for total period. Carcass characteristics of broilers had shown significant $(\mathrm{P}<0.05)$ superiority in treated groups. No specific trend was observed across dietary treatments, in weight of organs and processing losses. Better feed cost $/ \mathrm{kg}$ weight gain was observed in broilers fed on diets supplemented with neem and papaya leaf meal in a 1:1 ratio at $1.0 \%$ of the diet. It could be concluded that supplementation of neem and papaya leaf meal in $1: 1$ ratio at $1.0 \%$ of diet results in more healthy broilers.

\section{Introduction}

Poultry production is important for the socioeconomic development of any country and has ability to provide animal protein at shorter duration. There are many protein sources for human consumption but in view of ever rising demand of high protein; broiler production can serve as an alternative potential source to meet this burgeoning demand. The birds are ready for market and human consumption within 6-8 weeks period. It results in fast return of farmer's investment. As a result of this, collaborative efforts are required to discover ways and means to increase animal production to bridge the deficit in animal protein intake (Rahman et al., 2015). Many synthetic drugs like antibiotics and growth promoters are supplemented as a feed additive to broilers for their rapid growth. Their use has generated some positive and negative effects over the years and has redirected 
research to natural antimicrobial products. Feed additives like antibiotics and others use in broiler have residual effect and thereby causing serious health hazards in humans when consumed (Mali et al., 2020). It is evident that herbal agents are safer replacements as growth promoters because of their suitability, preference, lower production cost, reduced risks, toxicity and least health hazards (Kamal et al., 2015). Phytogenic feed additives are eventually gaining prominence in improving chicken performance and can boost their immune response (Oloruntola et al., 2016). In broilers, using leaf meal as feed constituents has been studied long (Wyllie and Chamanga, 1979). Leaf meals are welldefined as dried and pounded products of plant leaf.

Neem tree, Azadirachta indica is among the most examined tree in the world and has concerned world-wide importance due to its immense range of medicinal properties like antibacterial, antiviral, antiprotozoal, antifungal, hepatoprotective and various other properties, without showing any opposing effects (Kale et al., 2003). Whereas papaya tree, Carica papaya are natural source of papain, chymopapain $\mathrm{A}$ and $\mathrm{B}$, and papaya peptidase A. Papain is proteolytic in nature and consequently capable of increasing protein digestion (Oloruntola et al., 2018). Additionally, papaya leaf contains broad spectrum phytochemicals (including alkaloids and phenols).

Phenolic compounds have high antioxidant activity and free radical scavenging capacity, with the mechanism of inhibiting enzymes responsible for reactive oxygen species production (Kähkönen et al., 2001). The antibacterial, antifungal, antiviral and neuroprotective activities of papaya have also been recognized (Kadiri et al., 2016). Neem and papaya leaves (Azadirachta indica and Carica papaya) are considered to be the rich source of active ingredients which are important for growth of broilers (Adeyemo and Akanmu, 2012). Also, they are found abundantly in India and are easily available.

It is apparent that they could be used in broiler chicken feed as supplement with its beneficial nutritive and phytogenic potentials. It is hypothesized that NLM and PLM supplementation may improve beneficial effect by improving carcass characteristics and economics of broiler production. Keeping this in view, the present experiment was carried out to study: (1) Effect of neem leaf meal (NLM) and papaya leaf meal (PLM) supplementation on carcass yield of broilers; (2) Effect of NLM and PLM supplementation on economics of broiler production.

\section{Materials and Methods}

\section{Birds, Housing, and Experimental Design}

The present experiment was conducted in the Department of Animal Nutrition, College of Veterinary Science and Animal Husbandry, Jabalpur (M.P.). Experimental chicks were raised in the battery brooder house. Total of 220 , one day old VANCOBB broiler chicks were randomly selected for the experiment and were allotted eleven dietary treatments. Each treatment consisted of four replicates with five chicks in each.

The ingredients were procured in one lot for whole experiment. They were grinded and screened properly to get uniform particle size for formulation of diets. NLM and PLM were airdried; powdered separately and stored in air-tight bags. In the entire study uniform condition of housing, brooding, feeding and watering was maintained for all the groups of the experiment.

Eleven isonitrogenous and isocaloric dietary treatments was as follows: T0- Control 
(Standard broiler diet / basal diet); as per commercial chick feed specification, T1basal diet + neem leaf meal @ 0.5\% of diet, T2- basal diet + neem leaf meal @ 1.0\% of diet, T3- basal diet + papaya leaf meal @ $0.5 \%$ of diet, T4-basal diet + papaya leaf meal @ $1.0 \%$ of diet, T5- basal diet $+1: 1$ combination of neem leaf meal and papaya leaf meal @ 1.0\% of diet, T6- basal diet + 1:1 combination of neem leaf meal and papaya leaf meal @ 2.0\% of diet, T7- basal diet + 1:2 combination of neem leaf meal and papaya leaf meal @ 1.0\% of diet, T8- basal diet + 1:2 combination of neem leaf meal and papaya leaf meal @ 2.0\% of diet, T9- basal diet + 2:1 combination of neem leaf meal and papaya leaf meal @ 1.0\% of diet and T10- basal diet $+2: 1$ combination of neem leaf meal and papaya leaf meal @ 2.0\% of diet. The composition of feed ingredients used in the experiment is presented in Table 1 and Proximate Composition of NLM and PLM (on \% DM Basis) in Table .

\section{Carcass traits}

To study the carcass traits, two broilers (in each replicate) were slaughtered on end of research period. Broilers kept off feed (for twelve hours) before slaughter. Throughout this whole period, clean and fresh drinking water were provided ad-libitum. Before slaughter, broilers were weighed and then by giving cut to the jugular vein and then permitted to bleed completely.

On the iron rails birds were hanged in upturned position for complete bleeding, After complete bleeding, weight was noted. Then weight was again recorded after manual defeathering, for this hot water used (50$55^{\circ} \mathrm{C}$ ). The dressed weight was then recorded as follows:

Dressed weight $=$ Live weight - Weight loss as blood, head, feathers, shank and wing tips
After recording dressed weight, horizontal cut was given posterior to keel bone. Breast was pushed frontward to expose viscera and then pulled out. Weight of carcass was recorded again. Various visceral organs like liver, heart, giblet, gizzard and pancreas were weighed. The eviscerated weight was then recorded as follows:

Eviscerated weight $=$ Dressed weight - Weight of viscera

The drawn weight was then recorded as follows:

Drawn weight $=$ Eviscerated weight + Weight of giblet

Various processing losses such as blood, feathers, head, shank, separable fat and wing tips were recorded replicate wise during the study.

\section{Organs weight}

The organs (liver, heart, gizzard, spleen and pancreas) collected replicate wise at the time of slaughter and their weight was recorded during the experiment.

\section{Economics of production}

Economics of broiler production over feed cost was calculated as per cost of feed consumed and per $\mathrm{kg}$ weight gain for each dietary treatment.

\section{Statistical analysis}

Statistical analysis of the data was done by analysis of variance using completely randomize design (CRD) as per Snedecor and Cochran (1994). Differences among the treatments were tested for significance by Duncan's Multiple Range Test (1955). 


\section{Results and Discussion}

Effect of supplementation of neem and papaya leaf meal on carcass yield $(\%$ of live weight) of broilers

Treatment means of carcass yields in terms of percentage live weight showed that when broilers were fed on diets supplemented with neem and papaya leaf meal individually and in combination, their dressing yield, eviscerated weight and drawn weight in terms of percentage live weight of broilers influenced significantly. Present study demonstrates that birds fed on neem and papaya leaf meal in the ratio of 1:1 at $1.0 \%$ of total diet $(\mathrm{T} 5)$ showed $(\mathrm{P}<0.05)$ superiority in carcass characteristics of broilers as compared with control group. Increased dressing percentage value indicates higher edible meat obtained from birds fed specific treatment diet (Table 3).

Table.1 Ingredient composition of broiler experimental diets

\begin{tabular}{|l|c|c|c|}
\hline \multirow{2}{*}{ Feed Ingredients } & \multicolumn{3}{|c|}{ Experimental Diets (\%) } \\
\cline { 2 - 4 } & $\begin{array}{c}\text { Pre-starter } \\
(\mathbf{0}-\mathbf{1 4} \text { days })\end{array}$ & $\begin{array}{c}\text { Starter } \\
(\mathbf{1 5}-\mathbf{2 8} \text { days })\end{array}$ & $\begin{array}{c}\text { Finisher } \\
\mathbf{( 2 9} \mathbf{- 4 2} \text { days })\end{array}$ \\
\hline Maize & 55.21 & 57.33 & 59.27 \\
\hline Soybean meal & 38.83 & 35.10 & 31.52 \\
\hline Calcite/LSP & 0.62 & 0.66 & 0.69 \\
\hline DCP & 1.65 & 1.64 & 1.63 \\
\hline Vegetable oil & 2.28 & 3.91 & 5.60 \\
\hline Methionine & 0.22 & 0.22 & 0.21 \\
\hline Lysine & 0.28 & 0.28 & 0.22 \\
\hline Soda Bicarb & 0.10 & 0.10 & 0.10 \\
\hline Salt & 0.24 & 0.22 & 0.20 \\
\hline Trace Mineral Premix & 0.06 & 0.05 & 0.05 \\
\hline Vitamin Premix & 0.06 & 0.05 & 0.05 \\
\hline Threonine & 0.075 & 0.05 & 0.02 \\
\hline Maduramicin & 0.00 & 0.00 & 0.05 \\
\hline Robimidine & 0.033 & 0.033 & 0.00 \\
\hline Choline Chloride 60 \% & 0.10 & 0.12 & 0.15 \\
\hline Liver tonic & 0.05 & 0.05 & 0.05 \\
\hline Emulsifier & 0.05 & 0.05 & 0.05 \\
\hline Toxin binder & 0.10 & 0.10 & 0.10 \\
\hline Supplemental ingredient & + & + & + \\
\hline TOTAL & $\mathbf{9 9 . 9 9}$ & $\mathbf{9 9 . 9 9}$ & $\mathbf{9 9 . 9 9}$ \\
\hline
\end{tabular}

Trace mineral provided per kg diet: Manganese, 120mg; Zinc, 80mg; Iron, 25mg; Copper, 10mg; Iodine, 1mg; and Selenium, $0.1 \mathrm{mg}$

2 Vitamin premix provided per kg diet: Vitamin A, 20000IU; Vitamin D3, 3000IU; Vitamin E,10mg; Vitamin K,2mg; Riboflavin, 25mg; VitaminB1,1mg; Vitamin B6, 2mg; Vitamin B12,40mcg and Niacin, 15 $\mathrm{mg}$

+ Varying level of NLM and PLM supplement 
Table.2 Proximate Composition of NLM and PLM (on \% DM Basis)

\begin{tabular}{|l|c|c|}
\hline $\begin{array}{l}\text { Nutrient } \\
\text { Composition (\%) }\end{array}$ & NLM & PLM \\
\hline Moisture & 8.27 & 11.73 \\
\hline Crude Protein & 19.25 & 24.79 \\
\hline Crude Fibre & 15.78 & 7.64 \\
\hline Ether Extract & 5.02 & 1.70 \\
\hline Ash & 6.50 & 8.94 \\
\hline
\end{tabular}

Table.3 Carcass yields ( $\%$ of live weight) of broilers in different treatment groups

\begin{tabular}{|c|c|c|c|}
\hline \multirow[t]{2}{*}{ Treat. } & \multicolumn{3}{|c|}{ Parameters } \\
\hline & $\begin{array}{c}\text { Dressed weight } \\
(\%)\end{array}$ & $\begin{array}{l}\text { Eviscerated } \\
\text { weight }(\%)\end{array}$ & $\begin{array}{c}\text { Drawn } \\
\text { weight }(\%)\end{array}$ \\
\hline T0 & $76.46^{\text {de }}$ & $70.89^{\mathrm{de}}$ & $75.13^{\mathrm{de}}$ \\
\hline T1 & $78.89^{\mathrm{bc}}$ & $72.79^{\text {bcd }}$ & $77.24^{\text {bcd }}$ \\
\hline $\mathbf{T} 2$ & $80.16^{\mathrm{ab}}$ & $74.54^{b}$ & $79.10^{b}$ \\
\hline T3 & $79.83^{\mathrm{abc}}$ & $74.46^{\mathrm{b}}$ & $78.36^{\mathrm{bc}}$ \\
\hline T4 & $77.93^{\mathrm{cd}}$ & $72.05^{\mathrm{cd}}$ & $76.30^{\text {cde }}$ \\
\hline T5 & $81.23^{\mathrm{a}}$ & $76.68^{a}$ & $80.23^{\mathrm{a}}$ \\
\hline T6 & $78.35^{\mathrm{bc}}$ & $72.69^{\text {bcd }}$ & $76.31^{\text {cde }}$ \\
\hline $\mathbf{T 7}$ & $78.22^{\text {cd }}$ & $73.25^{b c}$ & $77.13^{\mathrm{bcd}}$ \\
\hline T8 & $78.77^{\mathrm{bc}}$ & $73.42^{\mathrm{bc}}$ & $77.94^{\mathrm{bc}}$ \\
\hline T9 & $79.26^{\mathrm{bc}}$ & $73.27^{\mathrm{bc}}$ & $78.17^{\mathrm{bc}}$ \\
\hline T10 & $75.52^{\mathrm{e}}$ & $69.71^{\mathrm{e}}$ & $74.63^{\mathrm{e}}$ \\
\hline SEM & 0.36 & 0.41 & 0.37 \\
\hline
\end{tabular}

Means of column with different superscript differ significantly $(\mathrm{P}<0.05)$

Table.4 Organs weight (\% of dressed weight) of broilers in different treatment groups

\begin{tabular}{|l|c|c|c|c|c|c|}
\hline \multirow{2}{*}{ Treat. } & \multicolumn{5}{|c|}{ Parameters $(\%)$} \\
\cline { 2 - 7 } & Heart & Gizzard & Liver & Spleen & Pancreas & Giblet \\
\hline T0 & $0.82^{\mathrm{ab}}$ & $1.87^{\mathrm{bc}}$ & 2.71 & $0.24^{\mathrm{a}}$ & $0.26^{\mathrm{b}}$ & $5.26^{\mathrm{abcd}}$ \\
\hline T1 & $0.70^{\mathrm{bc}}$ & $2.27^{\mathrm{ab}}$ & 2.62 & $0.09^{\mathrm{c}}$ & $0.29^{\mathrm{b}}$ & $5.53^{\mathrm{abc}}$ \\
\hline T2 & $0.84^{\mathrm{a}}$ & $2.36^{\mathrm{a}}$ & 2.55 & $0.10^{\mathrm{bc}}$ & $0.32^{\mathrm{b}}$ & $5.77^{\mathrm{ab}}$ \\
\hline T3 & $0.66^{\mathrm{c}}$ & $1.95^{\mathrm{abc}}$ & 2.35 & $0.12^{\mathrm{bc}}$ & $0.30^{\mathrm{b}}$ & $5.00^{\mathrm{bcd}}$ \\
\hline T4 & $0.74^{\mathrm{abc}}$ & $2.20^{\mathrm{ab}}$ & 2.57 & $0.11^{\mathrm{bc}}$ & $0.46^{\mathrm{a}}$ & $5.56^{\mathrm{abc}}$ \\
\hline T5 & $0.65^{\mathrm{c}}$ & $1.67^{\mathrm{c}}$ & 2.16 & $0.12^{\mathrm{bc}}$ & $0.30^{\mathrm{b}}$ & $4.55^{\mathrm{d}}$ \\
\hline T6 & $0.72^{\mathrm{abc}}$ & $2.07^{\mathrm{abc}}$ & 2.10 & $0.11^{\mathrm{bc}}$ & $0.32^{\mathrm{b}}$ & $5.11^{\mathrm{abcd}}$ \\
\hline T7 & $0.62^{\mathrm{c}}$ & $1.98^{\mathrm{abc}}$ & 2.33 & $0.13^{\mathrm{bc}}$ & $0.29^{\mathrm{b}}$ & $4.89^{\mathrm{cd}}$ \\
\hline T8 & $0.65^{\mathrm{c}}$ & $2.29^{\mathrm{ab}}$ & 2.75 & $0.14^{\mathrm{bc}}$ & $0.26^{\mathrm{b}}$ & $5.96^{\mathrm{a}}$ \\
\hline T9 & $0.82^{\mathrm{ab}}$ & $2.05^{\mathrm{abc}}$ & 2.64 & $0.14^{\mathrm{bc}}$ & $0.34^{\mathrm{b}}$ & $5.68^{\mathrm{abc}}$ \\
\hline T10 & $0.64^{\mathrm{c}}$ & $2.36^{\mathrm{a}}$ & 3.09 & $0.15^{\mathrm{b}}$ & $0.29^{\mathrm{b}}$ & $5.70^{\mathrm{abc}}$ \\
\hline SEM & 0.22 & 0.68 & 0.07 & 0.01 & 0.01 & 0.14 \\
\hline
\end{tabular}

Means of column with different superscript differ significantly $(\mathrm{P}<0.05)$ 
Table.5 Processing losses (\% of live weight) of broilers in different treatment groups

\begin{tabular}{|c|c|c|c|c|c|c|}
\hline \multirow{2}{*}{ Treat. } & \multicolumn{6}{|c|}{ Parameters (\%) } \\
\hline & Blood & Feather & Head & $\begin{array}{c}\text { Separable } \\
\text { fat }\end{array}$ & Appendages & $\begin{array}{l}\text { Processing } \\
\text { losses }\end{array}$ \\
\hline T0 & $7.96^{\mathrm{a}}$ & $6.67^{\mathrm{bcd}}$ & $2.87^{\mathrm{ab}}$ & 1.26 & $6.06^{\mathrm{b}}$ & $24.80^{\mathrm{ab}}$ \\
\hline T1 & $6.06^{\text {cde }}$ & $6.06^{\mathrm{cd}}$ & $2.95^{\mathrm{a}}$ & 1.30 & $6.05^{\mathrm{b}}$ & $22.42^{\text {cd }}$ \\
\hline T2 & $5.20^{\mathrm{f}}$ & $5.82^{\mathrm{d}}$ & $3.01^{\mathrm{a}}$ & 1.41 & $5.82^{\mathrm{de}}$ & $21.25^{\mathrm{de}}$ \\
\hline T3 & $5.29^{\mathrm{ef}}$ & $6.69^{\mathrm{abcd}}$ & $2.50^{\mathrm{de}}$ & 1.35 & $5.70^{\text {def }}$ & $21.53^{\text {cde }}$ \\
\hline T4 & $6.78^{\mathrm{bc}}$ & $6.62^{\mathrm{bcd}}$ & $2.64^{\mathrm{cd}}$ & 1.30 & $6.03^{b c}$ & $23.37^{\mathrm{bc}}$ \\
\hline T5 & $5.41^{\mathrm{ef}}$ & $5.86^{\mathrm{d}}$ & $2.45^{\mathrm{e}}$ & 1.37 & $5.06^{\mathrm{g}}$ & $25.14^{\mathrm{a}}$ \\
\hline T6 & $6.28^{\mathrm{cd}}$ & $7.30^{\mathrm{abc}}$ & $2.51^{\mathrm{de}}$ & 1.11 & $5.57^{\mathrm{f}}$ & $22.77^{\text {cd }}$ \\
\hline T7 & $5.92^{\text {det }}$ & $7.45^{\mathrm{ab}}$ & $2.58^{\text {cde }}$ & 1.42 & $5.85^{\mathrm{cd}}$ & $23.20^{\mathrm{bcd}}$ \\
\hline T8 & $6.38^{\text {cd }}$ & $6.48^{b c d}$ & $2.73^{b c}$ & 1.40 & $5.65^{\mathrm{ef}}$ & $22.63^{\text {cd }}$ \\
\hline T9 & $5.68^{\text {det }}$ & $6.23^{\text {bcd }}$ & $2.55^{\mathrm{de}}$ & 1.40 & $6.28^{a}$ & $22.14^{\text {cd }}$ \\
\hline T10 & $7.31^{\mathrm{ab}}$ & $7.94^{\mathrm{a}}$ & $2.89^{\mathrm{ab}}$ & 1.26 & $6.36^{\mathrm{a}}$ & $25.74^{\mathrm{a}}$ \\
\hline SEM & 0.19 & 0.16 & 0.04 & 0.04 & 0.07 & 0.35 \\
\hline
\end{tabular}

Means of column with different superscript differ significantly $(\mathrm{P}<0.05)$

Table.6 Economics (feed cost/kg body weight gain) of broiler production in different treatment groups

\begin{tabular}{|l|c|c|}
\hline Treat. & $\begin{array}{c}\text { Feed cost/kg } \\
\text { (Rs) }\end{array}$ & $\begin{array}{c}\text { Feed cost/kg } \\
\text { body weight gain } \\
\text { (Rs) }\end{array}$ \\
\hline T0 & 30.05 & $53.86^{\mathrm{a}}$ \\
\hline T1 & 30.07 & $52.52^{\mathrm{ab}}$ \\
\hline T2 & 30.08 & $51.63^{\mathrm{bc}}$ \\
\hline T3 & 30.07 & $51.02^{\mathrm{bcd}}$ \\
\hline T4 & 30.09 & $50.21^{\mathrm{cd}}$ \\
\hline T5 & 30.09 & $46.39^{\mathrm{f}}$ \\
\hline T6 & 30.12 & $49.72^{\mathrm{de}}$ \\
\hline T7 & 30.09 & $48.24^{\mathrm{e}}$ \\
\hline T8 & 30.13 & $48.49^{\mathrm{e}}$ \\
\hline T9 & 30.09 & $52.40^{\mathrm{ab}}$ \\
\hline T10 & 30.12 & $52.08^{\mathrm{b}}$ \\
\hline SEM & 0.01 & 0.35 \\
\hline
\end{tabular}

Means of column with different superscript differ significantly $(\mathrm{P}<0.05)$

In resemblance with our study, Adeyemo and Akanmu (2012), concluded that supplementation of diet with $1.0 \%$ NLM+PLM could improve dressing percentage of broiler. Similarly, Onyimonyi and Onu (2009) also observed that $2.0 \%$ inclusion of papaya leaf meal in the diet of finishing broilers could improve carcass yield in broilers. These findings were in corroboration with Shihab et al., (2017), who observed that broilers fed neem powder (1.0$3.0 \mathrm{~g} / \mathrm{kg}$ feed) can show significant 
improvement in dressing percent and carcass weight of broilers. In a previous study of Bonsu et al., (2012), they also reported no significant $(\mathrm{P}>0.05)$ effect of NLM diets (1.5$2.5 \%$ of total diet) on the percentage of internal organs of broilers across dietary treatments. By this we can state that since carcass yield is a sign of the quality and utilization of feed (Bamgbose and Niba, 1998), birds on Treatment 5 in our study had utilized their diet better, which was demonstrated by increased carcass yield.

Effect of supplementation of neem and papaya leaf meal on organs weight $(\%$ of dress weight) of broilers

Current study revealed that birds supplemented with varied levels of neem and papaya leaf meal produced significant $(\mathrm{P}<0.05)$ change in internal organ weight of broilers. But in absence of any specific trend across dietary treatment, weight of organs seems to have no effect of neem and papaya leaf meal supplementation (Table 4).

Findings of the present study showed an agreement with Adeyemo and Akanmu (2012), where they observed that after supplementation of diet with $1.0 \%$ NLM+PLM, \% weight of liver, heart, gizzard and lungs did not differ significantly $(\mathrm{P}>0.05)$, this might be because of the lowered level of anti-nutritional factors like limonoids (azadirachtin, salanin, nimbin, nimbidiol, etc.), which are triterpenoid compounds in the diet at this level of supplementation. Higher physiological activities by these organs are triggered by the presence of anti-nutritional factors and their associated effects. Contrary to present findings, Ahaotu et al., (2018) incorporated papaya leaf meal at levels of $0 \%, 5 \%, 10 \%$, and $15 \%$ in broiler diet and reported that $\%$ weight of gizzard, liver and heart were significantly $(\mathrm{P}<0.05)$ increased on papaya leaf meal supplementation.
Effect of supplementation of neem and papaya leaf meal on processing losses $(\%$ of live weight) of broilers

Current study revealed that diet fed with neem and papaya leaf meal in 1:1 ratio at $1.0 \%$ of total diet (T5) and in 2:1 ratio of $2.0 \%$ of total diet $(\mathrm{T} 10)$ had shown significantly $(\mathrm{P}<0.05)$ maximum processing losses $(25.14 \%$ and $25.74 \%$ ) compared to other groups (21.25$24.80 \%$ ). Overall processing losses in terms of head, blood, feather, separable fat and appendages (\% of live weight) showed that broilers supplemented with neem and papaya leaf meal have significant influence $(\mathrm{P}<0.05)$, but no specific trend has been observed which indicates no effect of treatment (Table 5).

Findings of the present study was in agreement with Haruna and Odunsi (2018) who supplemented papaya latex @ 0, 0.1, 0.15 and $0.2 \%$ to broilers and reported that there were significant variations $(\mathrm{P}<0.05)$ in the cut up parts (thigh, breast, neck, wing, back, drumstick and abdominal fat) without establishing any specific trend.

They observed that in a balanced and quality diet, papain enzyme might have no significant effect on carcass characteristics of broilers (Bharathidhasan et al., 2009, Hana et al., 2010, Davood et al., 2012, Azarfar, 2013 and Dalolio et al., 2015). In contrary to current study, Adeyemo and Akanmu (2012) reported that supplementation of diet with $1.0 \%$ NLM+PLM in broiler, did not significantly (P>0.05) influenced the \% weight of head and appendages.

\section{Effect of neem and papaya leaf meal on economics of broiler production}

As per the cost of ingredients used to prepare different diets in present study revealed that supplementation of neem and papaya leaf meal did not significantly $(\mathrm{P}>0.05)$ influenced the economics of broiler production in terms 
of feed cost $/ \mathrm{kg}$ but significantly $(\mathrm{P}<0.05)$ influenced feed cost $/ \mathrm{kg}$ body weight gain by different treatment groups. Data is presented in Table 6.

The better feed cost $/ \mathrm{kg}$ body weight gain of group T5 could be attributed by better growth performance and improved feed conversion ratio due to addition of neem and papaya leaf meal in broiler diet. These findings corroborated with the observations of Onyimonyi et al., (2009) who fed neem leaf meal at $0.5-2.5 \%$ of diet and Bonsu et al., (2012), who fed neem leaf meal at $1.5-2.5 \%$ dietary levels, found drop in production cost per bird, increased live weight, better FCR and higher gross profit in treated groups as compared to control group. Likewise, Deka et al., (2019) recommended that neem leaf powder at the level of $0.3 \%$ can be used economically as a natural feed additive in broiler chicken diet.

Similarly, Onyimonyi and Onu (2009) reported that broilers up to $2.0 \%$ inclusion level of papaya leaf meal could bring more economic returns to the farmer as evidenced by significantly lowered $(\mathrm{P}<0.05)$ feed cost/kg gain.

All these studies were in corroboration with the results of present study and stated that supplementation of neem and papaya leaf meal combination at lower level could be economical to farmers in terms of returns through broiler meal.

In conclusion the results revealed that by including neem and papaya leaf meal in the ratio of $1: 1$ at $1.0 \%$ of total diet in broilershas growth and health improvement potential and could be used as a feed additive for broiler production. The advantage of using neem and papaya leaf meal as a growth promoter is that these plants are readily available in India and can be easily collected at relatively no cost.

\section{Acknowledgement}

The authors are thankful to the NDVSU, Jabalpur and Dean, College of Veterinary Science and Animal Husbandry, Jabalpur, Madhya Pradesh for providing necessary amenities and financial support for this research work.

\section{References}

Ahaotu, E.O., Onyegbula, T. and Ahaotu, E.O. 2018. Haematological Characteristics and Organoleptic Test of Feeding Different Levels of Pawpaw (Carica papaya) Leaf Meal on Finisher Broiler Birds. International Journal of Animal and Veterinary Sciences, 5: 1014.

Adeyemo, G.O. and Akanmu, M.A. 2012. Effects of Neem (Azadirachta indica) and pawpaw (Carica papaya) leaves supplementation on performance and carcass characteristics of broilers. International Journal of Current Research, 4: 268-271.

Azarfar, A. 2013. Effect of hemicell enzyme on the performance, growth parameter, some blood factors and ileal digestibility of broiler chickens fed corn/soybean based diets. Journal of Cell and Animal Biology, 7(7): 85- 91.

Bamgbose, A.M. and Niba, A.T. 1998. Performance of broiler chickens fed cotton seed cake in starter and finisher rations. In: $3^{\text {rd }}$ annual conference of Animal Science Association of Nigeria, Lagos, 22-24, September 1998, The Nigerian livestock in the 21 st century, pp 84-87.

Bharathidhasan, A., Chandrasekaran, D., Natarajan, A., Ravi, R. and Ezhilvalavan, S. 2009. Effect of enzyme supplementation on carcass quality, intestinal viscosity and ileal digestabilities of broilers to nutrient 
reduced diet. Tamilnadu Journal of Veterinary and Animal Sciences, 5(6): 239-245.

Bonsu, F.R.K., Kagya-Agyemang, J.K., Kwenin, W.K.J. and Zanu, H.K. 2012. Medicinal response of broiler chickens to diets containing neem (Azadirachta indica) leaf meal, haematology and meat sensory analysis. World Applied Sciences Journal, 19: 800-805.

Davood, S., Farid, S. and Akbar, Y. 2012. Effects of inclusion of hull-less barley and enzyme supplementation of broiler diets on growth performance, nutrient digestion and dietary metabolizable energy content. Journal of Central European Agriculture, 13(1): 193 -207.

Dalólio, F.S., Vaz, D.P., Moreira, J., Albino, L.F.T. and Valadares, L.R. 2015. Carcass characteristics of broilers fed enzyme complex. Biotechnology in Animal Husbandry, 31(2): 153- 162.

Deka, J., Mahanta, J.D., Kalita, K.P., Choudhury, D., Ahmed, H.F. and Tamuly, S. 2019. Effect of dietary supplementation of Neem (Azadirachta indica) leaf powder on the performance of commercial broiler chicken. Journal of Entomology and Zoology Studies, 7(3): 658-663.

Duncan, D.B. (1955). Multiple range and multiple F tests. Biometrics, 11:1-42.

Haruna, M.A. and Odunsi, A.A. 2018. Growth Performance and Carcass Quality of Broiler Chickens Fed Dried Pawpaw (Carica papaya Linn) Latex. Journal of World Poultry Research, 8(2): 31-36.

Hana, A.H., Zakaria, M.A.R.J. and Majdi, A.A.I. 2010. The influence of supplemental multi-enzyme feed additive on the performance, carcass characteristics and meat quality traits of broiler chickens. International Journal of Poultry Science, 9(2): 126-133.

Kamal, A.B.M.M., Boby, F, Shahjada, Z,
Lutfuzzaman, A.K.M., Motin, A.A., Alam, K.J. and Mostofa, M. 2015. Effects of Neem, Nishyinda and Papaya leaves as growth promoters in broiler chicks. International Journal of Natural and Social Sciences, 2:49-55.

Kale, B.P., Kothekar, M.A., Tayade, H.P., Jaju, J.B. and Mateenuddin, M. 2003 Effect of aqueous extract of Azadirachta indica leaves on hepatotoxicity induced by antitubercular drugs in rats. Indian Journal of Pharmacology, 35: 177-180.

Kadiri, O., Olawoye, B., Fawale, O.S. and Adalumo, O.A. 2016. A review: Nutraceutical and antioxidant properties of the seeds, leaves and fruits of Carica papaya: Potential relevance to humans diet, the food industry and the pharmaceu-tical industry. Turkish Journal of Agriculture - Food Science and Technology, 4(12): 1039-1052.

Kähkönen, M.P., Hopia, A.I. and Heinonen, M. 2001. Berry phenolics and their antioxidant activity. Journal of Agricultural and Food Chemistry,49: 4076-4082.

Mali, P.D., Adangale, S.B., Sharma, N., Fulpagare, Y.G. and Patale, S.S. 2020. Effect of Supplementation of Neem (Azadirachta indica) Leaf Powder on Growth Performance and Carcass Characteristics of Broilers. International Journal ofCurrent Microbiology and Applied Sciences, 9(10): 70-74.

Oloruntola, O.D., Ayodele, S.O., Agbede, J.O. and Oloruntola, D.A. 2016. Effect of feeding broiler chickens with diets containing Alchornea cordifolia leaf meal and enzyme supplementation. Archivosde Zootecnea, 65: 489-498.

Oloruntola, O.D., Ayodele, S.O. and Oloruntola, D.A. 2018. Effect of pawpaw (Carica papaya) leaf meal and dietary enzymes on broiler 
performance, digestibility, carcass and blood composition. Revue délevage et de médicine vétérinaire des pays tropicaux, 71(3).

Onyimonyi, A.E. and Onu, E. 2009. An assessment of pawpaw leaf meal as protein ingredient for finishing broiler chickens. International Journal of Poultry Science, 8(10): 995-998.

Rahman, M.A., Ali, M.A., Saha, B.K., Hasan, M.A.A., Rahman, M.A. and Mostofa, M. 2015. Use of neem leaf and ginger extracts for cost effective broiler production. International Journal of Natural and Social Sciences, 2: 11-16.
Shihab, I.M., Mushtaq, T.B.A., Abdullah, S.M. and Mutar, S.S. 2017. Impact of supplementation Neem powder (Azadirachta indica) to diet broiler in immunological, physiological and productive traits. Advances in Environmental Biology, 11(3): 44-51.

Snedecor, G.W. and Cochran, W.G. 1994. Statistical Method, $8^{\text {th }}$ Edn., The lowa state university press, Ames, Lowa, USA.

Wyllie, D. and Chamanga, P.J. 1979. Cassava leaf meals in broiler diets. Tropical Animal Production, 4: 232-240.

\section{How to cite this article:}

Shiwani Singh, Ankur Khare, R. P. S. Baghel, Sunil Nayak, Ravi Prakash Pal, Amit Chaurasiya and Reddy, B. V. 2021. Effect of Feeding Neem and Papaya Leaf Meal as Feed Additive on Carcass Characteristics and Economics of Broilers. Int.J.Curr.Microbiol.App.Sci. 10(02): 29913000. doi: https://doi.org/10.20546/ijcmas.2021.1002.327 